\title{
Thiazoles and Thiazolidinones as COX/LOX Inhibitors
}

\author{
Konstantinos Liaras (iD), Maria Fesatidou (iD) and Athina Geronikaki * \\ Department of Pharmaceutical Chemistry, School of Pharmacy, Aristotle University, 54124 Thessaloniki, Greece; \\ liarasn@gmail.com (K.L.); fesa.maria@gmail.com (M.F.) \\ * Correspondence: geronik@pharm.auth.gr; Tel.: +30-231-099-7616
}

Academic Editor: Derek J. McPhee

Received: 28 February 2018; Accepted: 16 March 2018; Published: 18 March 2018

\begin{abstract}
Inflammation is a natural process that is connected to various conditions and disorders such as arthritis, psoriasis, cancer, infections, asthma, etc. Based on the fact that cyclooxygenase isoenzymes (COX-1, COX-2) are responsible for the production of prostaglandins that play an important role in inflammation, traditional treatment approaches include administration of non-steroidal anti-inflammatory drugs (NSAIDs), which act as selective or non-selective COX inhibitors. Almost all of them present a number of unwanted, often serious, side effects as a consequence of interference with the arachidonic acid cascade. In search for new drugs to avoid side effects, while maintaining high potency over inflammation, scientists turned their interest to the synthesis of dual COX/LOX inhibitors, which could provide numerous therapeutic advantages in terms of anti-inflammatory activity, improved gastric protection and safer cardiovascular profile compared to conventional NSAIDs. Thiazole and thiazolidinone moieties can be found in numerous biologically active compounds of natural origin, as well as synthetic molecules that possess a wide range of pharmacological activities. This review focuses on the biological activity of several thiazole and thiazolidinone derivatives as COX-1/COX-2 and LOX inhibitors.
\end{abstract}

Keywords: thiazole; thiazolidinone; COX; LOX; anti-inflammatory

\section{Introduction}

Inflammation is a natural process that is connected to various conditions and disorders such as arthritis, psoriasis, cancer, infections, asthma, etc. Based on the fact that cyclooxygenase isoenzymes (COX-1, COX-2) are responsible for the production of prostaglandins that play an important role in inflammation, traditional treatment approaches include administration of nonsteroidal anti-inflammatory drugs (NSAIDs), which act as selective or non-selective COX inhibitors [1-3].

It is well established that COX-1 inhibitors, such as acetylsalicylic acid, induce gastrointestinal irritation, due to the fact that this particular COX isoenzyme is responsible for the production of gastroprotective prostaglandins. Moreover, this group of drugs can be responsible for increased bleeding diathesis resulted from inhibiting COX-1 catalyzed production of thromboxane $\mathrm{A}_{2}\left(\mathrm{TXA}_{2}\right)$. The severity of side effects caused by COX-1 or combined COX-1/COX-2 inhibitors (e.g., ibuprofen) concentrated the scientific interest on the production of selective COX- 2 inhibitors, inspired by evidence supporting over-expression of this particular isoenzyme during inflammatory conditions. However, the hope for this new generation of drugs to be more effective than their predecessors and with less severe side effects was overshadowed by their association with increased myocardial infarction risk and cardiovascular thrombotic events. These severe side effects are mainly a result of inhibition of COX-2 catalyzed production of prostacyclin $\left(\mathrm{PGI}_{2}\right)$, a prostaglandin possessing vasodilatory and antiaggregatory properties [4-7]. 
In search for new drugs to avoid side effects, while maintaining high potency over inflammation, scientists turned their interest on leukotrienes and lipoxins, which are produced via the lipoxygenase (LOX) pathway and are associated with various procedures such as leucocytes activation and adhesion to vascular endothelium, bronchial asthma pathogenesis, formation of edema and gastric mucosa damage [2,8,9]. Consequently, dual COX/LOX inhibitors could provide numerous therapeutic advantages in terms of anti-inflammatory activity, improved gastric protection and safer cardiovascular profile compared to conventional NSAIDs. Therefore, in the recent years, a notable research effort in the field of dual-acting COX/LOX inhibitors with very promising results has been observed [10,11]. One of the eminent compounds that was a result of the above-mentioned scientific effort is licofelone (Figure 1), a dual COX/5-LOX inhibitor that was under production by the pharmaceutical industry, with mixed results of phase III of clinical trials for osteoarthritis patients [12]. While being a non-selective COX inhibitor, it simultaneously inhibits 5-lipoxygenase activating protein (FLAP) [13]. It was proved that polypharmacological activity of licofelone is supported by inhibition of mPGES-1 [14]. Recently, it was found that licofelone modulates neuroinflammation in the chronic phase of spinal cord injury [15]. It is believed that this action is due to elevation of levels of endogenous anti-oxidants and anti-inflammatory metabolites in the lesion site. In another publication, the effect of licofelone in intracerebroventricular streptozotocin-induced cognitive deficit in rats was observed [16]. Two other compounds that are mentioned in the literature as dual COX/LOX inhibitors are thiazol-4(5H)-one derivatives: darbufelone and CI-987 (Figure 1) [17].

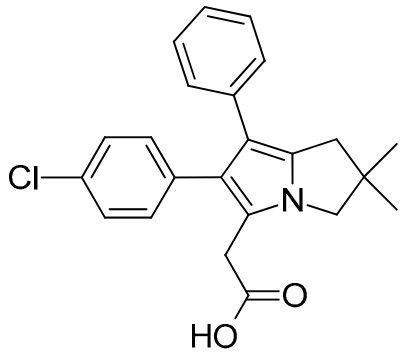

Licofelone<smiles>CCCCc1cc(/C=C2\SC(N)=NC2=O)cc([14CH3])c1O</smiles>

Darbufelone<smiles>[14CH3]c1cc(/C=C2\SC(O)=NC2=O)cc([18OH])c1O</smiles>

Cl-987

Figure 1. Chemical structures of Licofelone, Darbufelone and CI-987.

It is well established that compounds that contain sulfur atoms play a significant role in living organisms [18,19]. In particular, thiazole is a well-known heterocyclic aromatic compound that contains sulfur and nitrogen atoms at positions 1 and 3 of its five-member ring, respectively [20]. Thiazole moiety can be found in numerous biologically active compounds of natural origin (e.g., thiamine $[19,20]$, mycothiazole [21], cystothiazole C [22], as well as synthetic molecules possessing a wide range of pharmacological activities such as antimicrobial [23-28], antiviral [29,30], antitubercular [23,31], anti-inflammatory [32-34], anxiolytic [35], anaesthetic [36], anticonvulsant [37-40], etc.). There is a large number of known marketed drugs containing thiazole rings, such as the anthelmintic tiabendazole, the antibacterial sulfathiazole, the anticonvulsant riluzole, the anti-ulcer alizatidine, the antiparkinsonian talipexole, the antischistosomal niridazole, the antiviral ritonavir and the anti-inflammatory meloxicam. 
Thiazolidinones, on the other hand, are derivatives of thiazolidine, a saturated form of thiazole, with a carbonyl group at position 2, 4, or 5. The chemistry of thiazolidinones has drawn scientific interest through the years because this particular ring system is the core structure in a variety of synthetic compounds with a broad spectrum of biological activities, such as antimycobacterial [41,42], antifungal [43-46], anti-cancer [47-50], anticonvulsant [51-53], anti-edematous [54], antidiarrheal [55], anti-HIV [56,57], anti-platelet-activating factor [58], antidiabetic [59], antihistaminic [60], anti-inflammatory [61-63], analgesic [64,65], antimicrobial [66-69], antidepressant [70], etc.

This review focuses on the biological activity of several thiazole and thiazolidinone derivatives as COX-1/COX-2 and LOX inhibitors. Literature references that are included in this review were found using mainly Google Scholar, Scopus and SciFinder (keywords: thiazoles COX, thiazoles LOX, thiazolidinones COX, thiazolidinones LOX, NSAIDs, inflammation, thiazoles activity, thiazolidinones activity, etc.).

\section{Thiazoles as COX/LOX Inhibitors}

Therien et al. [71] reported the synthesis of a series of 5,6-diarylimidazo[2.1-b]thiazole derivatives and evaluated their possible inhibitory potential against COX-2 and COX-1 enzymes. As a result, compound 1 (Figure 2) was identified as a potent, orally active and selective inhibitor of the COX-2 enzyme. This result was confirmed by in vivo evaluation of anti-inflammatory activity.<smiles>COS(=O)(=O)c1ccc(-c2c(-c3ccccc3)nc3sccn23)cc1</smiles>

1

Figure 2. Chemical structure of 5,6-diarylimidazo[2.1-b]thiazole derivative 1.

Woods et al. [72] synthesized a series of 4-substituted thiazole analogues of indomethacin, which were tested as inhibitors of COX-1 and COX-2. It was found that compounds are selective inhibitors of COX-2 while only moderate COX-1 activity $(<57 \%$ inhibition at $10 \mathrm{mM})$ was observed. The most active compounds as COX-2 inhibitors appeared to be $\mathbf{2 a - c}$ (Figure 3) with $\mathrm{IC}_{50}$ values of $0.3,1$ and $7 \mathrm{nM}$, respectively.<smiles>[R]c1csc(Cc2c(C)n(C(=O)c3ccc(Cl)cc3)c3ccc(OC)cc23)n1</smiles><smiles>[R][14c]1[14cH][14c](Br)ccc1Br</smiles>

2a<smiles>Cc1csc2ccccc12</smiles>

2c

Figure 3. Chemical structures of 4-substituted thiazole analogues of indomethacin $2 \mathbf{a}-\mathbf{c}$. 
A series of N-aryl-4-aryl-1,3-thiazole-2-amine derivatives were synthesized by Suh et al. [73] as direct 5-LOX inhibitors. The SAR and chemical optimization studies revealed that, among 32 synthesized compounds, 3a, N-(3,5-dimethylphenyl)-4-(4-chlorophenyl)-1,3-thiazole-2-amine (Figure 4), was the most potent LOX inhibitor with $98 \%$ inhibition $\left(\mathrm{IC}_{50}=127 \mathrm{nM}\right)$ and $98 \%$ inhibition in a cell-based assay. Compounds $\mathbf{3} \mathbf{b}$ and $\mathbf{3} \mathbf{c}$ (Figure 4), although possessing strong LOX inhibitory activity, with $\mathrm{IC}_{50}$ values of 35 and $25 \mathrm{nM}$ respectively, cell-based assay results showed rather moderate potential.

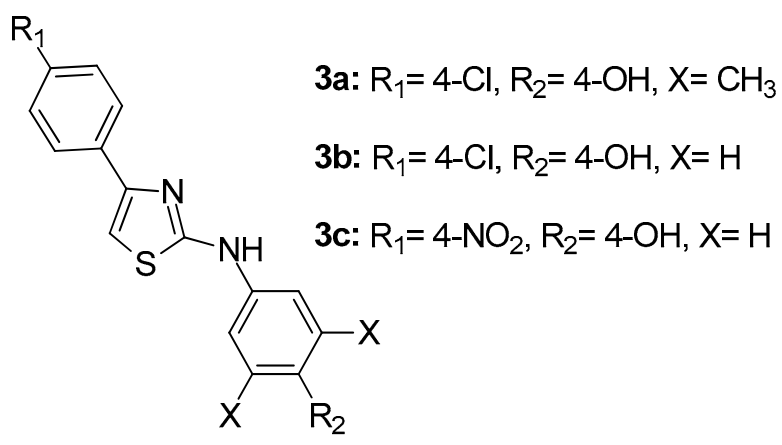

Figure 4. Chemical structures of N-aryl-4-aryl-1,3-thiazole-2-amine derivatives 3a-c.

Carradori et al. [74] reported the synthesis of novel 1-(4-ethyl carboxylate-thiazol-2-yl)3,5-di(hetero)aryl-2-pyrazoline derivatives as potential inhibitors of human COX isoenzymes. In vitro assay displayed promising selectivity against COX-1, with compound 4 (Figure 5) possessing the strongest activity with $\mathrm{IC}_{50}=29.60 \pm 1.58 \mu \mathrm{M}$, while none of the compounds exhibited COX-2 inhibition.

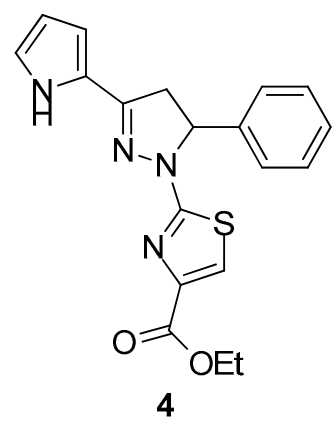

Figure 5. Chemical structure of 1-(4-ethylcarboxylate-thiazol-2-yl)-3,5-di(hetero)aryl-2-pyrazoline derivative 4 .

As a continuation of their research on the development of 15-LOX inhibitors [75], a series of new 3,6-diphenylimidazo[2,1-b]thiazol-5-amine derivatives were designed, synthesized and evaluated as inhibitors of the above enzyme by Tehrani et al. [76]. The study revealed that, among 14 synthesized and tested derivatives, $\mathbf{5 a - 5 d}$ (Figure 6) appeared to be the most potent with $\mathrm{IC}_{50}$ values ranging between 11.5-35 $\mu \mathrm{M}$. Compound 5a, with 2,4,4-trimethylpentan-2-yl pendent group, was the most active compound, being two times more potent than reference drug quercetin $\left(\mathrm{IC}_{50}=23 \mu \mathrm{M}\right)$.

According to docking studies, 5 a interacts properly with target enzyme 15-LOX, with hydrophobic interactions playing an important role in the binding process. 
<smiles>[R]CNc1c(-c2cccc([R3])c2)nc2scc(-c3ccccc3)n12</smiles>

$5 a$<smiles>[R]CC(C)(C)CC(C)(C)C</smiles>

$\mathrm{R}_{2} \quad \mathrm{R}_{3}$

$4-\mathrm{OCH}_{3} \mathrm{H}$

$5 b$<smiles>CC(C)(C)CC(C)(C)CC(C)(C)C</smiles>

4-Br

4- $\mathrm{NO}_{2}$

$5 \mathrm{c}\rangle \xi$

$\mathrm{H}$

4-Cl

$5 d$<smiles>CC(C)(C)C(C)(C)C</smiles>

$\mathrm{H} \quad 4-\mathrm{CH}_{3}$

Figure 6. Chemical structures of 3,6-diphenylimidazo[2,1-b]thiazol-5-amine derivatives 5a-5d.

Elachkar et al. [77] designed and synthesized two novel thiazole derivatives (Figure 7), namely compound 6a (N-[4-(4-hydroxy-3-methoxyphenyl)-1,3-thiazol-2-yl]acetamide) and compound $\mathbf{6 b}$ (4-(2-amino-1,3-thiazol-4-yl)-2-methoxyphenol), with aim to analyze their effect on COX isoforms. It was shown, using cell-stably over-expressing COX-1 and blood platelets, that compound 6a was a non-selective COX-1/COX-2 inhibitor, while $\mathbf{6 b}$ was a selective COX-2 inhibitor with similar $\mathrm{IC}_{50} \mathrm{~s}\left(\mathrm{IC}_{50} \mathrm{~s} 9.01 \pm 0.01 \mathrm{mM}\right.$ and $\left.11.65 \pm 6.20 \mathrm{mM}\right)$. Furthermore, these compounds demonstrated anti-inflammatory activity according to the dorsal air pouch model of inflammation.

Docking studies revealed that both compounds $6 \mathbf{a}$ and $\mathbf{6 b}$ bind to the COX-2 active site in a similar manner as celecoxib.<smiles>[R]c1sc(N)nc1-c1ccc(O)c(OC)c1</smiles>

6a: $\mathrm{R}=\mathrm{C}_{4} \mathrm{H}_{9}$

6b: $\mathrm{R}=\mathrm{CH}_{2} \mathrm{C}_{6} \mathrm{H}_{5}$

Figure 7. Chemical structures of compounds 6a (N-[4-(4-hydroxy-3-methoxyphenyl)-1,3-thiazol.-2-yl]acetamide) and $\mathbf{6 b}$ (4-(2-amino-1,3-thiazol-4-yl)-2-methoxyphenol).

Abdelall et al. [17], by modification of the celecoxib molecule, designed and synthesized some thiazolo-celecoxib analogues (7a-7j, Figure 8 ) and evaluated their anti-inflammatory, COX-1, COX-2 and 15-LOX inhibitory activity. 


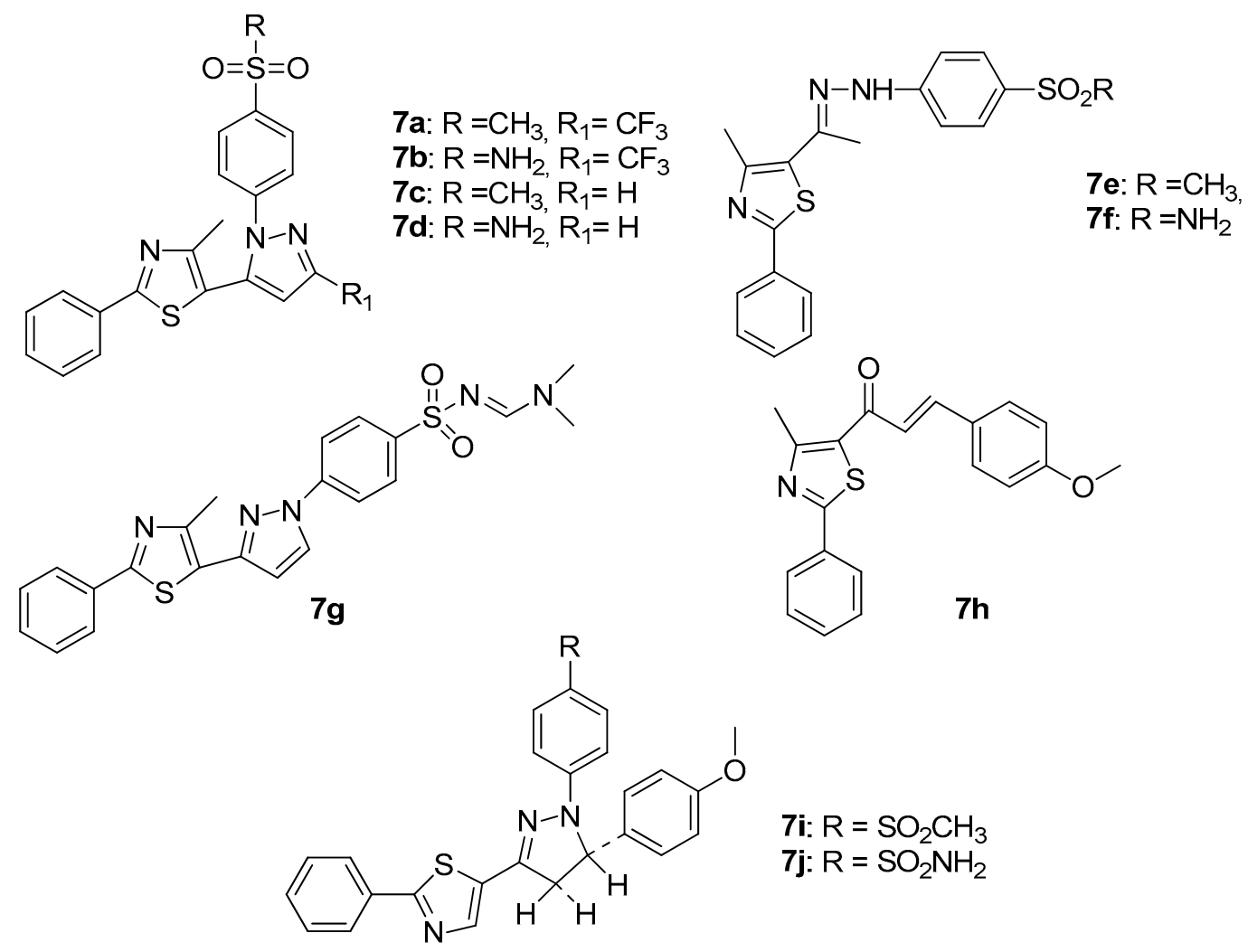

Figure 8. Structures of thiazolo-celecoxib analogues.

The study of COX-1, COX-2 as well as 15-LOX inhibitory activity revealed that all compounds possessed COX-1, COX-2 and 15 -LOX inhibitory potency. Compounds $7 \mathbf{a}, 7 \mathbf{b}, 7 \mathbf{7 e}$ and $7 \mathbf{i}$ were the most active COX-1 inhibitors, with $\mathrm{IC}_{50}$ values of $4.80-6.30 \mu \mathrm{M}$ being better than celecoxib, which was used as a reference drug $\left(\mathrm{IC}_{50} 7.60 \mu \mathrm{M}\right)$, but not better than aspirin. The same compounds appeared to be very potent COX-2 inhibitors $\left(\mathrm{IC}_{50} \mathrm{~s} 0.98-1.71 \mu \mathrm{M}\right.$ ) better than aspirin, while compounds $7 \mathbf{a}, 7 \mathbf{b}$ and $7 \mathbf{i}$ appeared to also be good 15-LOX inhibitors with $\mathrm{IC}_{50} \mathrm{~s}$ of 3.98-5.41 $\mu \mathrm{M}$, exhibiting higher potency than meclofenamate sodium that was used as a reference drug. Nevertheless, two compounds reached the goal of the authors. Compounds $7 \mathbf{a}$ and $7 \mathbf{i}$ possessed dual COX-2/15-LOX activity, despite their good COX-1 potency. This result proved the rationality of the authors' design.

Oniga et al. [7] designed and synthesized a series of new 2-(trimethoxyphenyl)-thiazoles aiming to develop new, safer and less toxic compounds as NSAIDs. In order to elucidate their mechanism of action, the authors performed evaluation of their COX-1/COX-2 inhibitory potency. In addition, docking studies were performed. It was found that four (8a-8d) out of thirteen tested compounds were the most active (Figure 9), even though no compound exhibited COX-1/COX-2 activity higher than reference drugs. Docking studies revealed that compounds $8 \mathrm{a}$ and $8 \mathrm{c}$ occupied area close to that of meloxicam, forming hydrogen bonds with the key amino acids Arg120, Ser530 of the active site of COX-2 enzyme. The similar behavior, regarding a COX-1 active site, was observed for the above-mentioned compounds. According to the authors, this is due to the homology similarity of active sites of two enzymes. The SAR studies revealed that substitution in position 4 of the phenyl ring is very important for the selectivity towards the COX-2 enzyme. 
<smiles>COc1cc(-c2nc(-c3ccccc3)cs2)cc(OC)c1OC</smiles>

$8 a$<smiles>COc1cc(-c2nc(-c3cccc4ccccc34)cs2)cc(OC)c1OC</smiles>

$8 c$<smiles>COc1cc(-c2nc(-c3ccc([N+](=O)[O-])cc3)cs2)cc(OC)c1OC</smiles>

$8 b$<smiles>COc1cc(-c2nc(-c3ccc(Cl)cc3)cs2)cc(OC)c1OC</smiles>

8d

Figure 9. Chemical structures of compounds 8a-d.

Novel 4,5-diarylthiazoles COX-1 inhibitors were reported by Abdelazeem and co-workers [78]. These compounds were designed and synthesized in order to be tested as COX inhibitors analogously to mofezolac and FR122047 (Figure 10), which lack a gastric damaging profile.<smiles>COc1ccc(-c2noc(CC(=O)O)c2-c2ccc(OC)cc2)cc1</smiles><smiles></smiles>

Figure 10. Chemical structures of COX inhibitors Mofezolac and FR122047.

These compounds were also evaluated for anti-inflammatory and analgesic activities. This study revealed that two compounds, $9 \mathbf{a}$ and $\mathbf{9 b}$ (Figure 11) were the most potent COX-1 inhibitors with $\mathrm{IC}_{50}$ values of 0.42 and $0.32 \mu \mathrm{M}$ and moderate COX-2 inhibitors with $\mathrm{IC}_{50} \mathrm{~s} 10.71$ and $9.23 \mu \mathrm{M}$, respectively. The studies concerning ulcerogenicity revealed a significantly tolerable gastric profile.<smiles>[R]c1ccc(-c2nc(NCC(=O)O)sc2-c2ccc([R])cc2)cc1</smiles>

Figure 11. Chemical structures of 4,5-diarylthiazoles $9 a$ and $\mathbf{9 b}$.

As a continuation of their previous research [78], Abdelazeem et al. [79] synthesized a series of novel diphenyl thiazole derivatives aiming to evaluate their anticancer activity.

Taking into account the growing interest of scientific community in studying the potential anticancer activity of COX-2 inhibitors, the authors evaluated anti-inflammatory and also COX inhibitory activity of compounds 10a-10g (Figures 12 and 13) that possessed the best anticancer profile against a panel of cancer cell lines (MCF-7, HT-29, A549). 
<smiles>Cc1ccc(NC(=S)NNC(=O)CNc2nc(-c3ccccc3)c(-c3ccccc3)s2)cc1</smiles><smiles>Cc1cc(C)n(C(=O)CNc2nc(-c3ccccc3)c(-c3ccccc3)s2)n1</smiles><smiles>CC1=NN(C(=O)CNc2nc(-c3ccccc3)c(-c3ccccc3)s2)C(=O)C1</smiles>

Figure 12. Chemical structures of diphenyl thiazole derivatives 10a-10c.

The most active as COX-1 inhibitor was $10 \mathrm{~b}\left(\mathrm{IC}_{50}=4.8 \mu \mathrm{M}\right)$, while $10 \mathrm{f}$, the most active anticancer compound against previously mentioned cell lines (with $\mathrm{IC}_{50}=0.96 \mu \mathrm{M}$ as COX-2 inhibitor) showed the highest selectivity index concerning this particular isoenzyme compared to diclofenac. Based on the fact that all tested compounds showed a good COX-2 selectivity, the authors came to the conclusion that there might be an important correlation between cancer treatment and the inhibition of the above-mentioned COX isoform.<smiles>O=C(CNc1nc(-c2ccccc2)c(-c2ccccc2)s1)N/N=C1\C(=O)Nc2ccccc21</smiles>

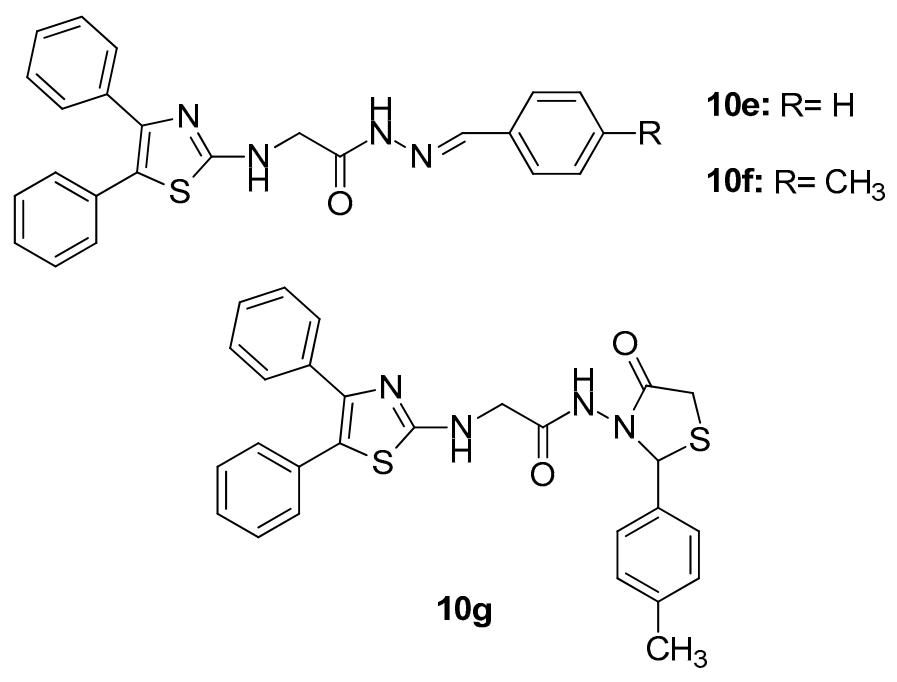

Figure 13. Chemical structures of diphenyl thiazole derivatives 10d-10g.

\section{Thiazolidinones as COX/LOX Inhibitors}

Ottana et al. [80], with the aim to ameliorate the activity of lead compound $\left(2 R, 2^{\prime} S\right) 3,3^{\prime}-(1,2-$ ethanediyl)bis(2-(3,4-dimethoxyphenyl)-thiazolidin-4-one [81], made some modifications such as removal of 3-methoxygroups of the benzene ring, retaining the 4-methoxy groups. The synthesized 
compound 11 (Figure 14) was screened for its anti-inflammatory activity as well as for its gastrointestinal safety [82]. The authors evaluated the new compound, after corresponding modifications, for its possible COX-1/COX-2 inhibitory activity. It was found that the novel compound is a better COX-2 inhibitor than the lead compound of this class, as it was observed inthe human whole blood assay and computational studies. The selectivity index COX-1/COX-2 appeared to be more than 30 times higher than that of a previously mentioned lead compound. Based on the findings, the authors confirmed the well-established fact that overproduction of COX-2 derived prostaglandins play a role in acute inflammation.

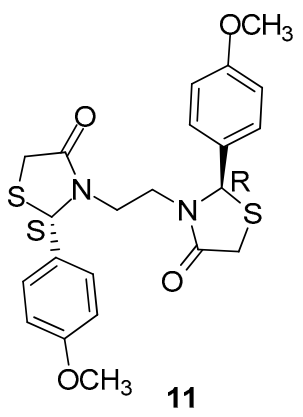

Figure 14. Chemical structure of 4-thiazolidinone derivative $\mathbf{1 1 .}$

Vigorita et al. [83] performed conformational studies as well as in situ molecular dynamics on previously synthesized [81] 3,3'-(1,2-ethanediyl)-bis[2-(3,4-dimethoxyphenyl)-4-thiazolidinones 12 (Figure 15), which were obtained as racemic mixtures (a) and mesomeric (b) forms $R R, S S, R S$, in order to better understand the binding mode of these forms to the active center of the enzymes. It was found that the $S S$ enantiomer exhibited the highest binding affinity score with interaction energy of $-47.15 \mathrm{kcal} / \mathrm{mol}$, while the $R R$ enantiomer showed low affinity for both COX isoforms. The meso form $R S$, although able to interact with both enzymes, showed, however, higher affinity for COX-2 with interaction energy $-46.88 \mathrm{kcal} / \mathrm{mol}$.

The authors, after in vitro evaluation of COX-1/COX-2 inhibitory activity, concluded that affinity order towards COX-1/COX-2 is following the order SS $>\mathrm{RS}>\mathrm{RR}$, in agreement with the theoretical results as well as previous in vivo data [82].

Theoretical results indicated SS > RS > RR affinity order towards COX-2 isoenzyme, in agreement with in vitro and previous in vivo pharmacological results.

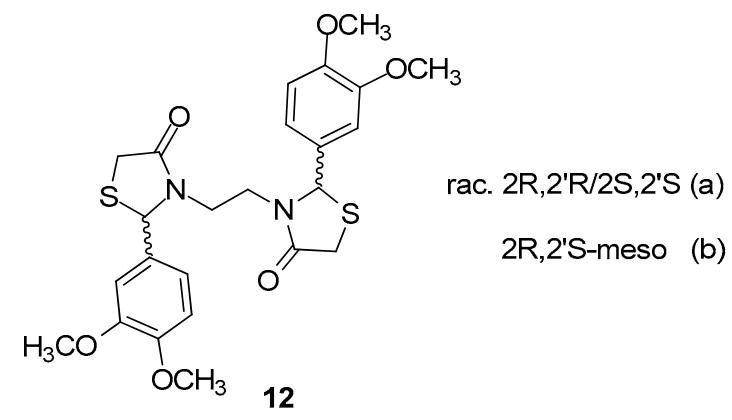

Figure 15. Chemical structures of racemic mixtures (a) and mesomeric (b) forms of 3,3'-(1,2ethanediyl)-bis[2-(3,4-dimethoxyphenyl)-4-thiazolidinone 12.

As a continuation of their previous work [80], Ottana et al. [84] reported the design and synthesis of 2-imino-4-thiazolidinones 13a, 13b and 5-arylidene-2-imino-4-thiazolidinones 14a-14f (Figure 16), which were evaluated for their in vivo anti-inflammatory activity by carrageenan-induced paw edema and pleurisy assays in rats [85,86]. Compound 14a, 5-(3-methoxypnenyliden)-2- 
phenylimino-3-propyl-4-thiazolidine, exhibited very good anti-inflammatory activity in this assay. With the aim of investigating their possible mechanism of action, their ability to inhibit COX-1 and COX-2 was assessed in the murine monocyte/macrophage J774 cell line [87]. Finally, the most promising among the tested compounds, $14 \mathrm{~d}$, was successfully docked into the active site of COX-2 enzyme, having as reference the known selective COX-2 inhibitor SC-558.

In this assay, compounds $\mathbf{1 3} \mathbf{a}$ and $\mathbf{1 3 b}$ exhibited only a weak inhibition of COX-1 isoform in all tested doses, without inhibiting COX-2. The introduction of a (Z)-5-arylidene group generally gave rise to the inhibition of COX-2 without reaching, however, the levels of the reference drugs.

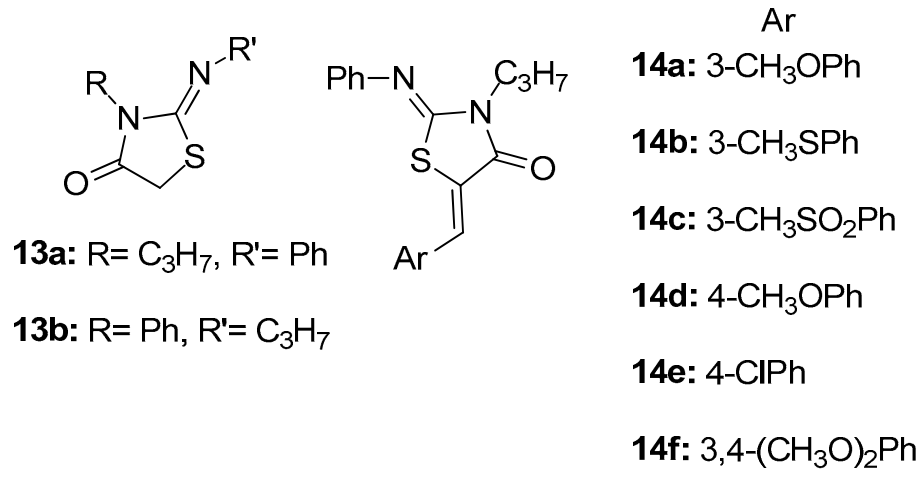

Figure 16. Chemical structures of 2-imino-4-thiazolidinone derivatives 13a, 13b and 5-arylidene2-imino-4-thiazolidinone derivatives 14a-14f.

Taranalli et al. [88] synthesized 11 thiazolidine-4-one compounds, 15a-h (Figure 17), and tested their anti-inflammatory activity in vitro (COX-1 and COX-2 inhibition) and in vivo (carrageenan-induced paw edema and cotton pellet-induced granulomas in rats). Most of the compounds showed significant inhibition of edema and granuloma dry weight, and, concerning in vitro COX-1 and COX-2 inhibition, half of the compounds tested showed maximum inhibition of COX-2, comparable to nimesulide. However, all tested compounds did not inhibit the COX-1 enzyme.

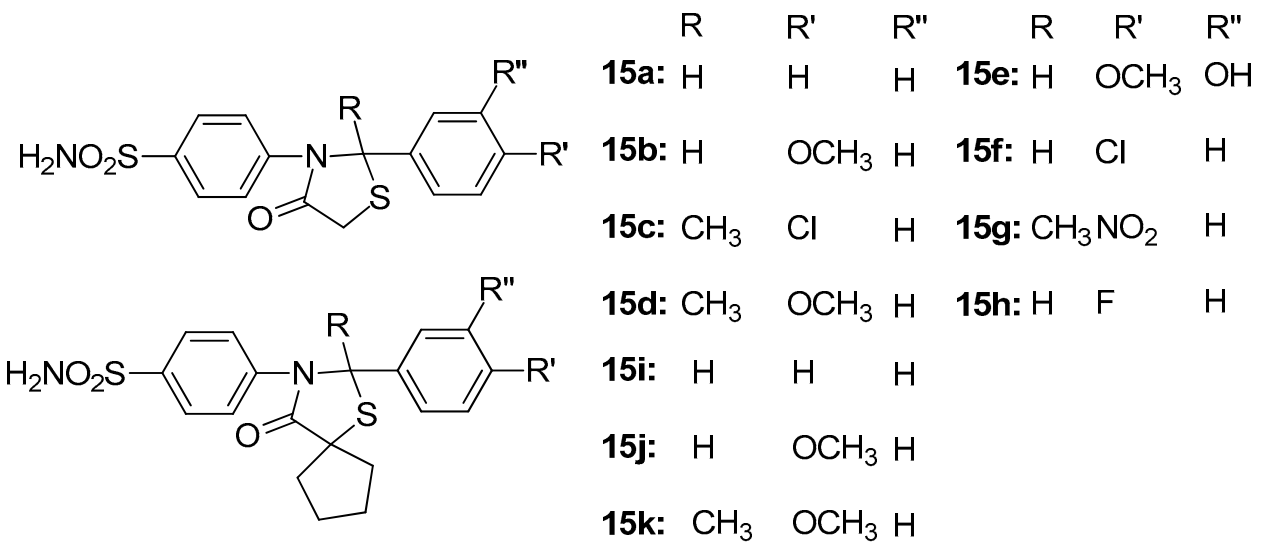

Figure 17. Chemical structures ofthiazolidine-4-one derivatives 15a-h.

In their study, Geronikaki et al. [89] reported the computer aided design, synthesis and biological evaluation of nine novel 5-arylidene-4-thiazolidinone derivatives that were chosen as candidates out of 22 compounds predicted to be COX/5-LOX dual inhibitors. It was found that compounds 16a, 16b (Figure 18) were dual COX-1/LOX inhibitors ( $\mathrm{IC}_{50} \mathrm{~s} 158 \mu \mathrm{M} / 116 \mu \mathrm{M}$ and $125 \mu \mathrm{M} / 125.9 \mu \mathrm{M}$, respectively), while compound $16 \mathrm{c}$ appeared to be the COX-1 inhibitor $\left(\mathrm{IC}_{50}=141 \mu \mathrm{M}\right)$. 


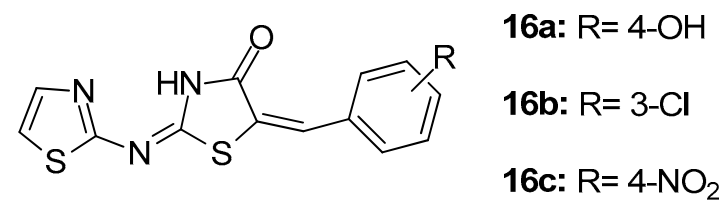

Figure 18. Chemical structures of 5-arylidene-4-thiazolidinones 16a-c.

Hofmann and co-workers [90] reported the design, virtual screening for LOX inhibitory activity and synthesis of a series of 35 5-benzylidene-2-phenylthiazolinones. These compounds were evaluated in intact polymorphonuclear leukocytes (PMNL) and a cell-free assay.

It was found that compound 17a (Figure 19) caused potent inhibition of 5-LOX product formation in intact PMNL and in cell-free PMNL S100 with $\mathrm{IC}_{50}$ values of 2 and $0.5 \mu \mathrm{M}$, respectively. In order to improve activity, the authors made several modifications on the parent compound that led to several derivatives, among which the most potent was found to be compound $\mathbf{1 7 b}$ (Figure 19), exhibiting the strongest LOX inhibitory activity with $\mathrm{IC}_{50} \mathrm{~s} 0.09 \mu \mathrm{M}$ and $0.28 \mu \mathrm{M}$ in both assays (intact PMNL and in cell-free PMNL S100).

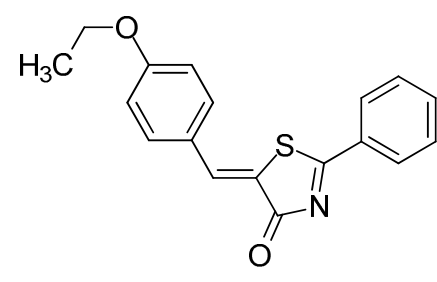

$17 a$

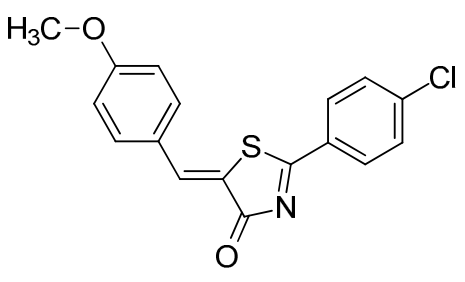

$17 b$

Figure 19. Chemical structures of 5-benzylidene-2-phenylthiazolinones 17a, 17b.

Hofmann et al. [91], taking into account their previous promising findings regarding ligand-based virtual screening of 5-benzylidene-2-phenyl-5H-thiazol-4-one derivatives [92] as LOX inhibitors, introduced structural modifications on compound $\mathbf{1 7 a}$. This led to the discovery of derivative 18 (Figure 20), which was investigated for its molecular pharmacological properties.

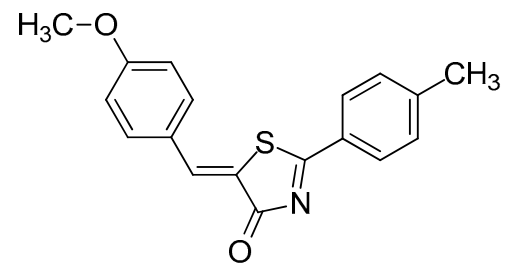

18

Figure 20. Chemical structure of 5-benzylidene-2-phenyl-5H-thiazol-4-one derivative 18.

A pharmacological profile was studied both in a cell-based system using human PMNL and cell-free assays utilizing PMNL homogenates, S100 preparations of the homogenates and partially purified recombinant 5-LOX. It was found that derivative $\mathbf{1 8}$ seems to be a promising novel 5-LOX inhibitor with $\mathrm{IC}_{50}$ values in the $\mathrm{nM}$ concentrations range in intact cells and cell-free assays. It would be interesting to point out that compound $\mathbf{1 8}$ had a completely different mode of action compared to previously studied inhibitors of this class. Nevertheless, this compound appeared to be highly selective for 5-LOX.

As a continuation of their previous work [89], Eleftheriou and co-workers [93], based on the knowledge that balanced modulation of several targets is crucial in the treatment of 
multifactorial diseases and knowing the inflammation mechanisms, proposed that balanced inhibition of COX-1/COX-2 and LOX enzymes could be a promising approach for the treatment of inflammation. Thus, a fragment-based library, focused on COX-1, COX-2 and LOX inhibition, by using chemoinformatics assays was created. As a result, 23 new benzothiazol-2-yliminothiazolidin-4-ones were designed and synthesized in order to evaluate their inhibitory activity on the above-mentioned enzymes. The evaluation of inhibitory activities revealed that most of the compounds showed potency against COX-1, with the best being compounds 19a, 19b and 19c (Figure 21), with $\mathrm{IC}_{50}$ values of 0.018 , 0.31 and $0.51 \mathrm{mM}$, respectively. Regarding COX-2, it was observed that the strongest inhibitory effect was exhibited by compound 19a (58.8\% inhibition), while, as far as LOX inhibition was concerned, almost all tested thiazolidinones were more potent than their thiazolyl analogues [89], having as a more potent compound $\mathbf{1 9 d}$ with $\mathrm{IC}_{50}=17.7 \mu \mathrm{M}$.

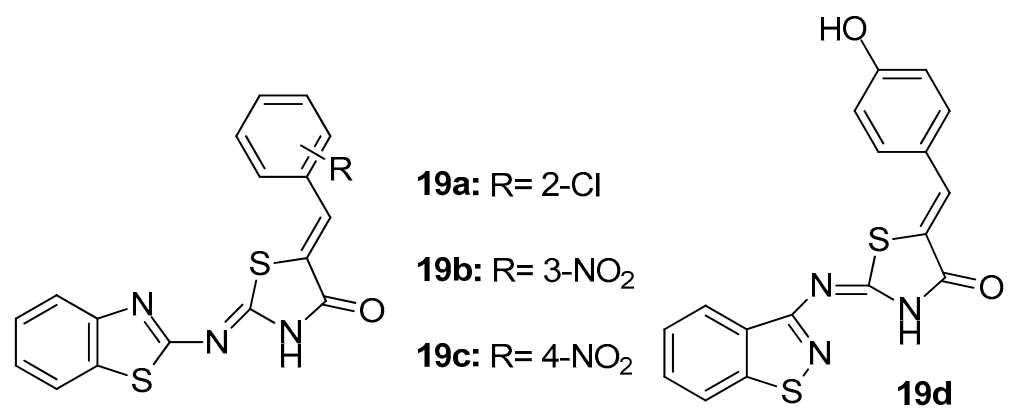

Figure 21. Chemical structures of benzothiazol-2-yliminothiazolidin-4-ones 19a-d.

Unsal-Tan et al. [94] reported the design of a series of novel 2-aryl-3-(4-sulfamoyl/ methylsulfonylphenylamino)-4-thiazolidinones with the aim to develop new selective cyclooxygenase-2 inhibitors using molecular modeling studies by the MOE program. The designed thiazolidinone derivatives with reasonable binding modes and high docking scores were synthesized and evaluated for their COX-1/COX-2 inhibitory activities with NS-398 and indomethacine used as reference compounds. The activity of these thiazolidinones was relatively moderate against COX-1 enzyme, with the best activity demonstrated by compound $20 \mathrm{a}\left(\mathrm{IC}_{50}=38.9 \mu \mathrm{M}\right)$. On the other hand, COX-2 inhibitory activity appeared to be slightly better than COX-1, with the best activity shown by compound $20 \mathrm{~b}\left(\mathrm{IC}_{50}=14.4 \mu \mathrm{M}\right)$ followed by compound $20 \mathrm{c}\left(\mathrm{IC}_{50}=20 \mu \mathrm{M}\right)$. The above-mentioned compounds are presented in Figure 22.

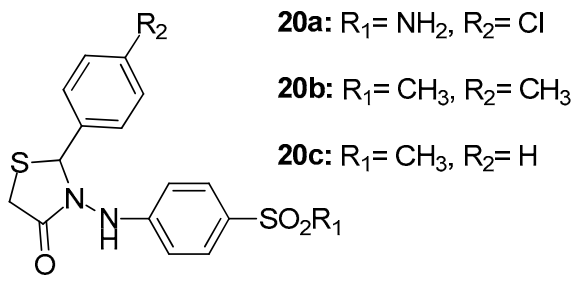

Figure 22. Chemical structures of 2-aryl-3-(4-sulfamoyl/methylsulfonylphenylamino)-4-thiazolidinones 20a-20c.

Based on their previous studies [89], Apostolidis and co-workers [95] described the synthesis of novel 5-arylidene-2-(1,3-thiazol-2-ylimino)-1,3-thiazolidin-4-ones introducing different substituents in position 4 of thiazole ring and evaluated their anti-inflammatory, COX-1/COX-2 and LOX inhibitory activities. In general, all compounds showed moderate to low inhibitory activity against all three enzymes. Nevertheless, compounds 21a and 21b (Figure 23) demonstrated good activity against COX-1 with $\mathrm{IC}_{50}$ s 16 and $10 \mu \mathrm{M}$, respectively. 


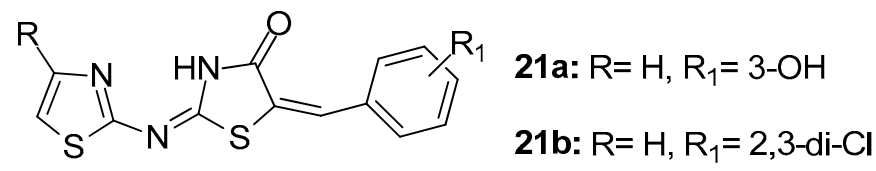

Figure 23. Chemical structures of 5-arylidene-2-(1,3-thiazol-2-ylimino)-1,3-thiazolidin-4-ones 21a, $21 \mathbf{b}$.

Abdelazeem et al. [96] synthesized and evaluated the in vivo and in vitro anti-inflammatory activity of a series of diphenylthiazole-thiazolidinone hybrids. The evaluation of COX-1/COX-2 inhibitory potency revealed that, in general, all compounds demonstrated moderate to high activity. It was shown that the potency of compounds depends on the substituent on the thiazolidinone ring. Thus, replacement of five membered thiophene ring with pyridine or phenyl rings significantly increased the COX-1 inhibitory activity and selectivity.

Consequently, compounds 22a and 22b (Figure 24) appeared to be the most potent COX-1 inhibitors with $\mathrm{IC}_{50}$ values of 3.51 and $2.03 \mu \mathrm{M}$, respectively. The introduction of the bulky naphthyl group in position 5 of thiazolidinone ring resulted in compound 22c (Figure 24) with strong COX-2 inhibition $\left(\mathrm{IC}_{50}=3.84 \mu \mathrm{M}\right)$. These in vitro results are in accordance with results of in vivo experiments and molecular docking.<smiles>O=C1N/C(=N\c2nc(-c3ccccc3)c(-c3ccccc3)s2)S/C1=C/c1cccnc1</smiles><smiles>O=C1N/C(=N\c2nc(-c3ccccc3)c(-c3ccccc3)s2)S/C1=C/c1cccc([N+](=O)[O-])c1</smiles><smiles>O=C1N/C(=N\c2nc(-c3ccccc3)c(-c3ccccc3)s2)S/C1=C/c1cccc2ccccc12</smiles>

Figure 24. Chemical structures of diphenylthiazole-thiazolidinone hybrids 22a-c.

As part of their ongoing studies on the synthesis of safe anti-inflammatory agents, Abdellatif et al. [97] designed and synthesized two series of new thiazolidin-4-ones as potential COX-2 selective inhibitors. Among the synthesized compounds, 23a and 23b (Figure 25) exhibited in general, the strongest in vitro COX-2 potential ( IC $_{50} \mathrm{~s} 2.3$ and $1.9 \mu \mathrm{M}$, respectively) and selectivity (SIs 4.56 and 5.68 , respectively). Nevertheless, these two compounds showed good COX-1 inhibitory activity $\left(\mathrm{IC}_{50} \mathrm{~S}\right.$ 10.5 and $10.8 \mu \mathrm{M}$, respectively) as well. It should be noted that these results were in agreement with in vivo and molecular docking data.<smiles>[R]c1ccc(C2SC(C)C(=O)N2Nc2ccc(S(N)(=O)=O)cc2)cc1</smiles>

Figure 25. Chemical structures of thiazolidinone derivatives 23a, 23b. 
Ashour et al. [98] presented the synthesis and evaluation of in vitro/in vivo anti-inflammatory activity of new pyrazolyl benzenesulfonamides linked to polysubstituted pyrazoles and thiazolidinones. Among these two series of compounds, thiazolidinone derivatives and specifically compounds $24 \mathbf{a}$ and $\mathbf{2 4 b}$ (Figure 26) appeared to be the most potent COX-1/COX-2 inhibitors ( $\mathrm{IC}_{50} \mathrm{~s}$ $5.6 / 1.52$ and $4.5 / 1.06 \mu \mathrm{M}$, SIs 3.68 and 4.24, respectively). It should be mentioned that, in general, the enzymatic inhibitory activity coincided with the results of the rat paw edema assay.

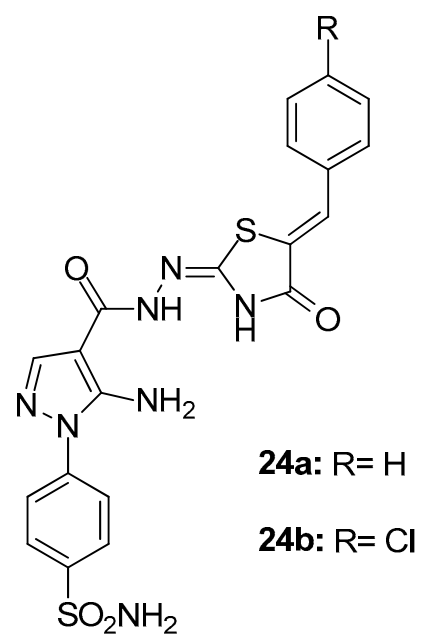

Figure 26. Chemical structures of pyrazolyl benzenesulfonamide derivatives 24a, 24b.

Fourteen 2-imino-4-thiazolidinone derivatives have been synthesized and evaluated by Ali et al. [99] for their in vivo anti-inflammatory activity. In order to elucidate the mechanism of action, docking on the COX-2 enzyme has been performed for all compounds. Based on docking results, three compounds, 25a, 25b and 25c (Figure 27) were chosen for testing their COX-1/COX-2 inhibitory activity. The evaluation revealed that compound 25c, with the highest anti-inflammatory activity and best glide energy among these three, appeared to also be the strongest COX-2 inhibitor with $\mathrm{IC}_{50}=3.29 \mu \mathrm{M}$ and $\mathrm{SI}=29.00$.<smiles>O=C(COc1ccc(Cl)cc1Cl)N/N=C1/SCC(=O)N1c1ccc(Br)cc1</smiles>

25a<smiles>CCCc1ccc(N2C(=O)CS/C2=N/NC(=O)COc2ccc(Cl)cc2Cl)cc1</smiles>

25b<smiles>O=C(COc1ccc(Cl)cc1Cl)N/N=C1/SCC(=O)N1Cc1ccccc1</smiles>

Figure 27. Chemical structures of 2-imino-4-thiazolidinone derivatives 25a-c. 
Geronikaki et al. [100] used docking analysis to predict the effectiveness of new designed compounds (26a-26k, Figure 28) by insertion of adamantanyl moiety to previously synthesized and tested as COX/LOX inhibitors 2-thiazolylimino-5-arylidene-4-thiazolidinones [89]. It was found that compound 26c had the best estimated binding energies to LOX and COX-2 $(-12.57 \mathrm{kcal} / \mathrm{mol}$ and $-12.54 \mathrm{kcal} / \mathrm{mol}$ ), while the best estimated binding energy to COX-1 was observed for compound $26 \mathrm{~d}(-12.13 \mathrm{kcal} / \mathrm{mol})$. It should be mentioned that, in all seven pairs of previously synthesized and new adamantanyl derivatives (26a-26f and 26i), the estimated binding energy of the adamantanyl derivatives was lower than that of the non-substituted analogues for all three enzymes, showing a better predicted activity for the adamantanyl compounds.
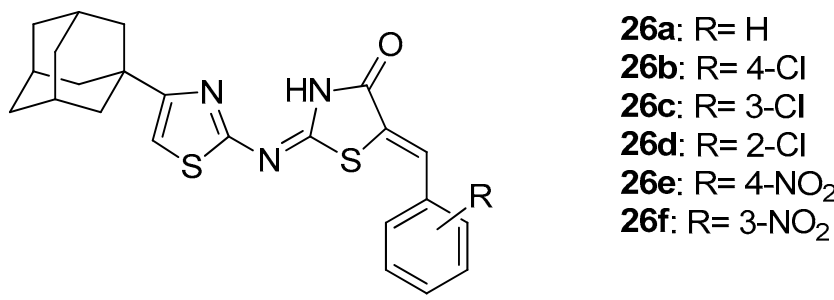

\author{
26g: $\mathrm{R}=2-\mathrm{NO}_{2}$ \\ 26h: $\mathrm{R}=4-\mathrm{OH}$ \\ 26i: $\mathrm{R}=4-\mathrm{OH}, 3-\mathrm{OMe}$ \\ 26j: $\mathrm{R}=4-\mathrm{OMe}$ \\ 26k: $\mathrm{R}=4-\mathrm{OH}, 3,5-\mathrm{OMe}$
}

Figure 28. Chemical structures of 4-adamantanyl-2-thiazolylimino-5-arylidene-4-thiazolidinones.

Moreover, new adamantanyl derivatives, 26g and 26h were designed and evaluated using docking analysis. These two compounds did not have pairs with previous synthesized compounds. It was found that their predicted binding energies to COX and LOX enzymes was low, especially for compound $26 \mathrm{~g}(-12.22 \mathrm{kcal} / \mathrm{mol})$. The evaluation of LOX inhibitory activity revealed that compounds 26c-26e, 26g, 26h and 26k exhibited good activity with $\mathrm{IC}_{50} \mathrm{~s} 38,98,45,34,60$ and $56 \mu \mathrm{M}$, respectively. As far as COX-1 inhibition is concerned, the best activity was found to possess compounds $\mathbf{2 6 \mathbf { d }}$ and $\mathbf{2 6 \mathbf { b }}$ ( $\mathrm{IC}_{50} \mathrm{~s} 39 \mu \mathrm{M}$ and $50 \mu \mathrm{M}$ respectively). Thus, experimental results coincide with docking, confirming the rational design of these thiazolidinone derivatives.

\title{
4. SAR
}

The analysis of the structure-activity relationship of thiazole derivatives used in this review revealed that thiazole based thiazolidinones were moderate to good COX-1/LOX inhibitors. The most favorable substituents in benzene ring appeared to be $4-\mathrm{NO}_{2}, 3-\mathrm{NO}_{2}$ and 3-Cl. Introduction of a methyl group in positions 4 and 5 of thiazole rings led to compounds with only COX-1 inhibitory activity. LOX activity was lost. The introduction of adamantanyl substituent in position 4 of thiazole ring showed good LOX inhibitory activity. Furthermore, the presence of 2- $\mathrm{NO}_{2}, 4-\mathrm{NO}_{2}, 3-\mathrm{Cl}, 4-\mathrm{Cl}$ and 4-OH-3,5-OMe substituents in benzene rings increased LOX inhibition compared to unsubstituted rings. Introduction of 2 phenyl rings in positions 4,5 of thiazole rings led to COX-1/COX-2 inhibitors with the prevalence of COX-2 inhibition. The best activity against COX-2 was observed for compounds with bulky naphthalene group. Thiazolidinone derivatives with hydrazinocarbonyl pyrazolo benzensulfonamide group led to compounds with good COX-2 and moderate COX-1 potency. Introduction of phenylin position 4 of thiazolidin-4-one as well as benzensulfonamide group linked to nitrogen of the ring resulted in compounds with good COX-2 and moderate COX-1 activity. Linkage of two 3,4-dimethoxyphenylthiazolidine-4-one molecules together through the ethane link resulted in good COX-2 inhibitors with a high COX-1/COX-2 selectivity index.

The benzothiazole based thiazolidinones were much better as COX-1 inhibitors compared to thiazole-based thiazolidinones as well as better LOX inhibitors. The most favorable substituents on the benzene ring for COX-1 inhibition were 2-Cl, 4-Cl and 4- $\mathrm{NO}_{2,}$, while, for $\mathrm{LOX}$, the substituents that improved activity were 2- $\mathrm{NO}_{2}, 3-\mathrm{OH}, 4-\mathrm{OH}, 4-\mathrm{OMe}, 4-\mathrm{OH}, 3-\mathrm{OMe}$ and 4-OH, 3,5-OMe. Replacement of the benzothiazole ring with benzoisothiazole resulted in less active compounds as COX-1 inhibitors, but substituents 2- $\mathrm{NO}_{2}, 4-\mathrm{NO}_{2}, 4-\mathrm{Cl}, 4-\mathrm{OH}$ and 4-OH-3-OMe substantially increased the LOX activity. 
It was observed that, in general, the hybride molecules with thiazole and other heterocycles with bulky and lipophilic substituents expressed good COX-2 inhibitory potency. The same good activity resulted from a combination of thiazole with celecoxib, as well as phenyl substituted fused thiazole derivatives.

\section{Conclusions}

Over recent decades, much effort was dedicated to the development of new COX/LOX inhibitors. Specifically, there is a significant amount of publications concerning the synthesis and evaluation of thiazoles and thiazolidinones with potential COX/LOX inhibitory activity. Nevertheless, although a great amount of synthesized compounds were found to be potent as COX/LOX inhibitors, only a portion of them revealed a safer pharmacological profile, compared to marketed anti-inflammatory drugs. However, from the above-mentioned studies, it is clear that thiazole and thiazolidinone derivatives can be promising targets for future research in the field of COX/LOX inhibitors in order to discover new, more effective and safer anti-inflammatory drugs.

Author Contributions: K.L. and M.F. reviewed the articles and analyzed data. K.L. and A.G. designed the review procedure. K.L. wrote the introduction and designed the chemical structures in all figures. K.L., M.F. and A.G. drafted the main part of the manuscript. K.L. and A.G. wrote the conclusions. A.G. provided general oversight and mentorship, including data interpretation and suggested revisions. M.F. had the overall care of references editing.

Conflicts of Interest: The authors declare no conflict of interest.

\section{References}

1. Leval, X.; Julémont, F.; Delarge, J.; Pirotte, B.; Dogné, J.-M. New trends in dual 5-LOX/COX inhibition. Curr. Med. Chem. 2002, 9, 941-962. [CrossRef] [PubMed]

2. Martel-Pelletier, J.; Lajeunesse, D.; Reboul, P.; Pelletier, J.-P. Therapeutic role of dual inhibitors of 5-LOX and COX, selective and non-selective non-steroidal anti-inflammatory drugs. Ann. Rheum. Dis. 2003, 62, 501-509. [CrossRef] [PubMed]

3. Araniciu, C.; Parvu, A.; Tiperciuc, B.; Palage, M.; Oniga, S.; Verite, P.; Oniga, O. Synthesis and evaluation of the anti-inflammatory activity of some 2-(trimethoxyphenyl)-4-R1-5-R2-thiazoles. Dig. J. Nanomater. Biostruct. 2013, 8, 699-709.

4. Patrono, C.; Rocca, B. Aspirin and Other COX-1 Inhibitors. In Antiplatelet Agents; Gresele, P., Born, G.V.R., Patrono, C., Page, C.P., Eds.; Springer: Berlin/Heidelberg, Germany, 2012; pp. 137-164, ISBN 978-3-642-29423-5.

5. Baigent, C.; Bhala, N.; Emberson, J.; Merhi, A.; Abramson, S.; Arber, N.; Baron, J.A.; Bombardier, C.; Cannon, C.; Farkouh, M.E.; et al. Vascular and upper gastrointestinal effects of non-steroidal anti-inflammatory drugs: Meta-analyses of individual participant data from randomised trials. Lancet 2013, 382, 769-779. [CrossRef]

6. Bansal, S.; Bala, M.; Suthar, S.K.; Choudhary, S.; Bhattacharya, S.; Bhardwaj, V.; Singla, S.; Joseph, A. Design and synthesis of novel 2-phenyl-5-(1,3-diphenyl-1H-pyrazol-4-yl)-1,3,4-oxadiazoles as selective COX-2 inhibitors with potent anti-inflammatory activity. Eur. J. Med. Chem. 2014, 80, 167-174. [CrossRef] [PubMed]

7. Oniga, S.; Pacureanu, L.; Stoica, C.; Palage, M.; Craciun, A.; Rusu, L.; Crisan, E.; Araniciu, C. COX Inhibition Profile and Molecular Docking Studies of Some 2-(Trimethoxyphenyl)-Thiazoles. Molecules 2017, 22, 1507-1821. [CrossRef] [PubMed]

8. Penrose, J.F.; Austen, K.F.; Lam, B.K. Leukotrienes: Biosynthetic Pathways, Release and Receptor-Mediated Actions with Relevance to Disease States. In Inflammation: Basic Principles and Clinical Correlates; Gallin, J.L., Snyderman, R., Eds.; Lippicort Williams \& Wilkins: Philadelphia, PA, USA, 1999; pp. 361-372.

9. Aparoy, P.; Reddy, K.K.; Reddanna, P. Structure and ligand based drug design strategies in the development of novel 5-LOX inhibitors. Curr. Med. Chem. 2012, 19, 3763-3778. [CrossRef] [PubMed]

10. Hansen, F.K.; Khankischpur, M.; Tolaymat, I.; Mesaros, R.; Dannhardt, G.; Geffken, D. Efficient synthesis and 5-LOX/COX-inhibitory activity of some 3-hydroxybenzo[b]thiophene-2-carboxylic acid derivatives. Bioorg. Med. Chem. Lett. 2012, 22, 5031-5034. [CrossRef] [PubMed] 
11. Ghatak, S.; Vyas, A.; Misra, S.; O’Brien, P.; Zambre, A.; Fresco, V.M.; Markwald, R.R.; Swamy, K.V.; Afrasiabi, Z.; Choudhury, A.; et al. Novel di-tertiary-butyl phenylhydrazones as dual cyclooxygenase-2/5-lipoxygenase inhibitors: Synthesis, COX/LOX inhibition, molecular modeling, and insights into their cytotoxicities. Bioorg. Med. Chem. Lett. 2014, 24, 317-324. [CrossRef] [PubMed]

12. Kulkarni, S.; Singh, V. Licofelone-a novel analgesic and anti-inflammatory agent. Curr. Top. Med. Chem. 2007, 7, 251-263. [CrossRef] [PubMed]

13. Fischer, L.; Hornig, M.; Pergola, C.; Meindl, N.; Franke, L.; Tanrikulu, Y.; Dodt, G.; Schneider, G.; Steinhilber, D.; Werz, O. The molecular mechanism of the inhibition by licofelone of the biosynthesis of 5-lipoxygenase products. Br. J. Pharmacol. 2007, 152, 471-480. [CrossRef] [PubMed]

14. Koeberle, A.; Siemoneit, U.; Buhring, U.; Northoff, H.; Laufer, S.; Albrecht, W.; Werz, O. Licofelone suppresses prostaglandin E2 formation by interference with the inducible microsomal prostaglandin E2 synthase-1. J. Pharmacol. Exp. Ther. 2008, 326, 975-982. [CrossRef] [PubMed]

15. Dulin, J.; Karoly, E.; Wang, Y.; Strobel, H.; Grill, R. Licofelone modulates neuroinflammation and attenuates mechanical hypersensitivity in the chronic phase of spinal cord injury. J. Neurosci. 2013, 33, 652-664. [CrossRef] [PubMed]

16. Kumar, A.; Sharma, S.; Prashar, A.; Deshmukh, R. Effect of licofelone-a dual COX/5-LOX inhibitor in intracerebroventricular streptozotocin-induced behavioral and biochemical abnormalities in rats. J. Mol. Neurosci. 2015, 55, 749-759. [CrossRef] [PubMed]

17. Abdelall, E.; Kamel, G. Synthesis of new thiazolo-celecoxib analogues as dual cyclooxygenase-2/ 15-lipoxygenase inhibitors: Determination of regio-specific different pyrazole cyclization by 2D NMR. Eur. J. Med. Chem. 2016, 118, 250-258. [CrossRef] [PubMed]

18. Fontecave, M.; Ollagnier-De-Choudens, S.; Mulliez, E. Biological radical sulfur insertion reactions. Chem. Rev. 2003, 103, 2149-2166. [CrossRef] [PubMed]

19. De Souza, M.V.N. Synthesis and biological activity of natural thiazoles: An important class of heterocyclic compounds. J. Sulfur Chem. 2005, 26, 429-449. [CrossRef]

20. Dondoni, A. New Perspectives in Thiazole Chemistry. Phosphorus Sulfur Relat. Elem. 1985, $24,1-38$. [CrossRef]

21. Crews, P.; Kakou, Y.; Quiñoà, E. Mycothiazole, a Polyketide Heterocycle from a Marine Sponge. J. Am. Chem. Soc. 1988, 110, 4365-4368. [CrossRef]

22. Liu, Y.; Sun, X.; Zhang, X.; Liu, J.; Du, Y. Concise synthesis of 2,4-disubstituted thiazoles from $\beta$-azido disulfides and carboxylic acids or anhydrides: Asymmetric synthesis of cystothiazole C. Org. Biomol. Chem. 2014, 12, 8453-8461. [CrossRef] [PubMed]

23. Shiradkar, M.R.; Murahari, K.K.; Gangadasu, H.R.; Suresh, T.; Kalyan, C.A.; Panchal, D.; Kaur, R.; Burange, P.; Ghogare, J.; Mokale, V.; et al. Synthesis of new S-derivatives of clubbed triazolyl thiazole as anti-Mycobacterium tuberculosis agents. Bioorg. Med. Chem. 2007, 15, 3997-4008. [CrossRef] [PubMed]

24. Karegoudar, P.; Karthikeyan, M.S.; Prasad, D.J.; Mahalinga, M.; Holla, B.S.; Kumari, N.S. Synthesis of some novel 2,4-disubstituted thiazoles as possible antimicrobial agents. Eur. J. Med. Chem. 2008, 43, 261-267. [CrossRef] [PubMed]

25. Liaras, K.; Geronikaki, A.; Glamočlija, J.; Ćirić, A.; Soković, M. Thiazole-based chalcones as potent antimicrobial agents. Synthesis and biological evaluation. Bioorg. Med. Chem. 2011, 19, 3135-3140. [CrossRef] [PubMed]

26. Liaras, K.; Geronikaki, A.; Glamočlija, J.; Ćirić, A.; Soković, M. Thiazole-based aminopyrimidines and $N$-phenylpyrazolines as potent antimicrobial agents: Synthesis and biological evaluation. Med. Chem. Commun. 2014, 5, 915-922. [CrossRef]

27. Reddy, G.M.; Garcia, J.R.; Reddy, V.H.; de Andrade, A.M.; Camilo, A., Jr.; Pontes, R.A.P.; de Lazaro, L. Synthesis, antimicrobial activity and advances in structure-activity relationships (SARs) of novel tri-substituted thiazole derivatives. Eur. J. Med. Chem. 2016, 123, 508-513. [CrossRef] [PubMed]

28. Bondock, S.; Fouda, A.M. Synthesis and evaluation of some new 5-(hetaryl)thiazoles as potential antimicrobial agents. Synth. Commun. 2018, 48, 561-573. [CrossRef]

29. El-Sabbagh, O.I.; Baraka, M.M.; Ibrahim, S.M.; Pannecouque, C.; Andrei, G.; Snoeck, R.; Balzarini, J.; Rashad, A.A. Synthesis and antiviral activity of new pyrazole and thiazole derivatives. Eur. J. Med. Chem. 2009, 44, 3746-3753. [CrossRef] [PubMed] 
30. Dawood, K.M.; Eldebss, T.M.A.; El-Zahabi, H.S.A.; Yousef, M.H. Synthesis and antiviral activity of some new bis-1,3-thiazole derivatives. Eur. J. Med. Chem. 2015, 102, 266-276. [CrossRef] [PubMed]

31. Aridoss, G.; Amirthaganesan, S.; Kim, M.S.; Kim, J.T.; Jeong, Y.T. Synthesis, spectral and biological evaluation of some new thiazolidinones and thiazoles based on t-3-alkyl-r-2,c-6-diarylpiperidin-4-ones. Eur. J. Med. Chem. 2009, 44, 4199-4210. [CrossRef] [PubMed]

32. Kalkhambkar, R.G.; Kulkarni, G.M.; Shivkumar, H.; Rao, R.N. Synthesis of novel triheterocyclicthiazoles as anti-inflammatory and analgesic agents. Eur. J. Med. Chem. 2007, 42, 1272-1276. [CrossRef] [PubMed]

33. Kouatly, O.; Geronikaki, A.; Kamoutsis, C.; Hadjipavlou-Litina, D.; Eleftheriou, P. Adamantane derivatives of thiazolyl-N-substituted amide, as possible non-steroidal anti-inflammatory agents. Eur. J. Med. Chem. 2009, 44, 1198-1204. [CrossRef] [PubMed]

34. Mohareb, R.M.; Zaki, M.Y.; Abbas, N.S. Synthesis, anti-inflammatory and anti-ulcer evaluations of thiazole, thiophene, pyridine and pyran derivatives derived from androstenedione. Steroids 2015, 98, 80-91. [CrossRef] [PubMed]

35. Geronikaki, A.; Babaev, E.; Dearden, J.; Dehaen, W.; Filimonov, D.; Galaeva, I.; Krajneva, V.; Lagunin, A.; MacAev, F.; Molodavkin, G.; et al. Design, synthesis, computational and biological evaluation of new anxiolytics. Bioorg. Med. Chem. 2004, 12, 6559-6568. [CrossRef] [PubMed]

36. Geronikaki, A.; Vicini, P.; Dabarakis, N.; Lagunin, A.; Poroikov, V.; Dearden, J.; Modarresi, H.; Hewitt, M.; Theophilidis, G. Evaluation of the local anaesthetic activity of 3-aminobenzo[ $d$ ]isothiazole derivatives using the rat sciatic nerve model. Eur. J. Med. Chem. 2009, 44, 473-481. [CrossRef] [PubMed]

37. Dawood, K.M.; Abdel-Gawad, H.; Rageb, E.A.; Ellithey, M.; Mohamed, H.A. Synthesis, anticonvulsant, and anti-inflammatory evaluation of some new benzotriazole and benzofuran-based heterocycles. Bioorg. Med. Chem. 2006, 14, 3672-3680. [CrossRef] [PubMed]

38. Amin, K.M.; Rahman, D.E.A.; Al-Eryani, Y.A. Synthesis and preliminary evaluation of some substituted coumarins as anticonvulsant agents. Bioorg. Med. Chem. 2008, 16, 5377-5388. [CrossRef] [PubMed]

39. Ghabbour, H.A.; Kadi, A.A.; Eltahir, K.E.H.; Angawi, R.F.; El-Subbagh, H.I. Synthesis, biological evaluation and molecular docking studies of thiazole-based pyrrolidinones and isoindolinediones as anticonvulsant agents. Med. Chem. Res. 2015, 24, 3194-3211. [CrossRef]

40. Łączkowski, K.Z.; Sałat, K.; Misiura, K.; Podkowa, A.; Malikowska, N. Synthesis and anticonvulsant activities of novel 2-(cyclopentylmethylene)hydrazinyl-1,3-thiazoles in mouse models of seizures. J. Enzym. Inhib. Med. Chem. 2016, 31, 1576-1582. [CrossRef] [PubMed]

41. Srivastava, T.; Gaikwad, A.K.; Haq, W.; Sinha, S.; Katti, S.B. Synthesis and biological evaluation of 4-thiazolidinone derivatives as potential antimycobacterial agents. ARKIVOC 2005, 2005, 120-130.

42. Bhat, M.A. Synthesis and anti-mycobacterial activity of new 4-thiazolidinone and 1,3,4-oxadiazole derivatives of isoniazid. Acta Pol. Pharm. 2014, 71, 763-770. [PubMed]

43. Verma, A.; Saraf, S.K. 4-Thiazolidinone-A biologically active scaffold. Eur. J. Med. Chem. 2008, 43, 897-905. [CrossRef] [PubMed]

44. Kunzler, A.; Neuenfeldt, P.D.; das Neves, A.M.; Pereira, C.M.; Marques, G.H.; Nascente, P.S.; Fernandes, M.H.; Hübner, S.O.; Cunico, W. Synthesis, antifungal and cytotoxic activities of 2-aryl-3-((piperidin-1-yl)ethyl)thiazolidinones. Eur. J. Med. Chem. 2013, 64, 74-80. [CrossRef] [PubMed]

45. Marques, G.H.; Kunzler, A.; Bareño, V.D.O.; Drawanz, B.B.; Mastelloto, H.G.; Leite, F.R.M.; Nascimento, G.G.; Nascente, P.S.; Siqueira, G.M.; Cunico, W. Antifungal activity of 3-(heteroaryl-2-ylmethyl)thiazolidinone derivatives. Med. Chem. 2014, 10, 355-360. [CrossRef] [PubMed]

46. Chen, N.; Duan, W.; Lin, G.; Liu, L.; Zhang, R.; Li, D. Synthesis and antifungal activity of dehydroabietic acid-based 1,3,4-thiadiazole-thiazolidinone compounds. Mol. Divers. 2016, 20, 897-905. [CrossRef] [PubMed]

47. Gududuru, V.; Hurh, E.; Dalton, J.T.; Miller, D.D. Synthesis and antiproliferative activity of 2-aryl-4-oxo-thiazolidin-3-yl-amides for prostate cancer. Bioorg. Med. Chem. Lett. 2004, 14, 5289-5293. [CrossRef] [PubMed]

48. Zhou, H.; Wu, S.; Zhai, S.; Liu, A.; Sun, Y.; Li, R.; Zhang, Y.; Ekins, S.; Swaan, P.W.; Fang, B.; et al. Design, synthesis, cytoselective toxicity, structure-activity relationships, and pharmacophore of thiazolidinone derivatives targeting drug-resistant lung cancer cells. J. Med. Chem. 2008, 51, 1242-1251. [CrossRef] [PubMed] 
49. Szychowski, K.A.; Leja, M.L.; Kaminskyy, D.V.; Binduga, U.E.; Pinyazhko, O.R.; Lesyk, R.B.; Gmiński, J. Study of novel anticancer 4-thiazolidinone derivatives. Chem.Biol. Interact. 2017, 262, 46-56. [CrossRef] [PubMed]

50. Ansari, M.F.; Idrees, D.; Hassan, M.I.; Ahmad, K.; Avecilla, F.; Azam, A. Design, synthesis and biological evaluation of novel pyridine-thiazolidinone derivatives as anticancer agents: Targeting human carbonic anhydrase IX. Eur. J. Med. Chem. 2018, 144, 544-556. [CrossRef] [PubMed]

51. Kaur, H.; Kumar, S.; Vishwakarma, P.; Sharma, M.; Saxena, K.K.; Kumar, A. Synthesis and antipsychotic and anticonvulsant activity of some new substituted oxa/thiadiazolylazetidinonyl/thiazolidinonylcarbazoles. Eur. J. Med. Chem. 2010, 45, 2777-2783. [CrossRef] [PubMed]

52. Shingalapur, R.V.; Hosamani, K.M.; Keri, R.S.; Hugar, M.H. Derivatives of benzimidazole pharmacophore: Synthesis, anticonvulsant, antidiabetic and DNA cleavage studies. Eur. J. Med. Chem. 2010, 45, 1753-1759. [CrossRef] [PubMed]

53. Nikalje, A.P.; Ansari, A.; Bari, S.; Ugale, V. Synthesis, biological activity, and docking study of novel isatin coupled thiazolidin-4-one derivatives as anticonvulsants. Arch. Pharm. 2015, 348, 433-445. [CrossRef] [PubMed]

54. Vazzana, I.; Terranova, E.; Mattioli, F.; Sparatore, F. Aromatic Schiff bases and 2,3-disubstituted-1,3thiazolidin-4-one derivatives as antiinflammatory agents. ARKIVOC 2004, 2004, 364-374.

55. Mazzoni, O.; Di, B.; Grieco, P.; Novellino, E.; Bertamino, A.; Borrelli, F.; Capasso, R.; Diurno, M.V. Synthesis and pharmacological activity of 2-(substituted)-3-\{2-[(4-phenyl-4-cyano) piperidino]ethyl\}-1,3-thiazolidin-4-ones. Chem. Biol. Drug Des. 2006, 67, 432-436. [CrossRef] [PubMed]

56. Pitta, E.; Crespan, E.; Geronikaki, A.; Giovanni, M.; Samuele, A. Novel thiazolidinone derivatives with an uncommon mechanism of inhibition towards HIV-1 reverse transcriptase. Lett. Drug Des. Discov. 2010, 7 , 228-234. [CrossRef]

57. Suryawanshi, R.; Jadhav, S.; Makwana, N.; Desai, D.; Chaturbhuj, D.; Sonawani, A.; Idicula-Thomas, S.; Murugesan, V.; Katti, S.B.; Tripathy, S.; et al. Evaluation of 4-thiazolidinone derivatives as potential reverse transcriptase inhibitors against HIV-1 drug resistant strains. Bioorg. Chem. 2017, 71, 211-218. [CrossRef] [PubMed]

58. Tanabe, Y.; Okumura, H.; Nagaosa, M.; Murakami, M. Highly stereoselective synthesis of the anti-platelet activating factor, 4-thiazolidinones, using silyl derivatives of 2-mercaptoalkanoic acids. Bull. Chem. Soc. Jpn. 1995, 68, 1467-1472. [CrossRef]

59. Imran, M.; Yar, M.S.; Khan, S.A. Synthesis and antihyperglycemic activity of 2-(substituted phenyl)-3-\{[4-(1-naphthyl)-1,3-thiazol-2-yl] amino\}-4-oxo-1,3-thiazolidin-5-ylacetic acid derivatives. Acta Pol. Pharm. 2009, 66, 51-56. [PubMed]

60. Diurno, M.V.; Mazzoni, O.; Piscopo, E.; Calignano, A.; Giordano, F.; Bolognese, A. Synthesis and Antihistaminic Activity of Some Thiazolidin-4-ones. J. Med. Chem. 1992, 35, 2910-2912. [CrossRef] [PubMed]

61. Kumar, A.; Rajput, C.S.; Bhati, S.K. Synthesis of 3-[4'-(p-chlorophenyl)-thiazol-2'-yl]-2-[(substituted azetidinone/thiazolidinone)-aminomethyl]-6-bromoquinazolin-4-ones as anti-inflammatory agent. Bioorg. Med. Chem. 2007, 15, 3089-3096. [CrossRef] [PubMed]

62. Rao, P.P.N.; Kabir, S.N.; Mohamed, T. Nonsteroidal anti-inflammatory drugs (NSAIDs): Progress in small molecule drug development. Pharmaceuticals 2010, 3, 1530-1549. [CrossRef] [PubMed]

63. Maccari, R.; Vitale, R.M.; Ottanà, R.; Rocchiccioli, M.; Marrazzo, A.; Cardile, V.; Graziano, A.C.E.; Amodeo, P.; Mura, U.; Del, C. Structure-activity relationships and molecular modelling of new 5-arylidene-4-thiazolidinone derivatives as aldose reductase inhibitors and potential anti-inflammatory agents. Eur. J. Med. Chem. 2014, 81, 1-14. [CrossRef] [PubMed]

64. Knutsen, L.J.S.; Hobbs, C.J.; Earnshaw, C.G.; Fiumana, A.; Gilbert, J.; Mellor, S.L.; Radford, F.; Smith, N.J.; Birch, P.J.; Russell, B.; et al. Synthesis and SAR of novel 2-arylthiazolidinones as selective analgesic N-type calcium channel blockers. Bioorg. Med. Chem. Lett. 2007, 17, 662-667. [CrossRef] [PubMed]

65. Taranalli, A.D.; Thimmaiah, N.V.; Srinivas, S.; Saravanan, E.; Bhat, A.R. Anti-inflammatory, analgesic and anti ulcer activity of certain thiazolidinones. Asian J. Pharm. Clin. Res. 2009, 2, 79-83.

66. Vicini, P.; Geronikaki, A.; Incerti, M.; Zani, F.; Dearden, J.; Hewitt, M. 2-Heteroarylimino-5-benzylidene-4thiazolidinones analogues of 2-thiazolylimino-5-benzylidene-4-thiazolidinones with antimicrobial activity: Synthesis and structure-activity relationship. Bioorg. Med. Chem. 2008, 16, 3714-3724. [CrossRef] [PubMed] 
67. Patel, N.B.; Patel, S.D. Synthesis and in vitro antimicrobial study of schiff base and thiazolidinone of 1-cyclopropyl-6-fluoro-7-[4-(2,3-dichlorophenyl)piperazin-1-yl]-4-quinolone. Acta Pol. Pharm. 2010, 67, 45-53. [PubMed]

68. Omar, K.; Geronikaki, A.; Zoumpoulakis, P.; Camoutsis, C.; Soković, M.; Ćirić, A.; Glamočlija, J. Novel 4-thiazolidinone derivatives as potential antifungal and antibacterial drugs. Bioorg. Med. Chem. 2010, 18, 426-432. [CrossRef] [PubMed]

69. Angapelly, S.; Sri, R.; SunithaRani, R.; Kumar, C.G.; Kamal, A.; Arifuddin, M. Ultrasound assisted, VOSO $_{4}$ catalyzed synthesis of 4-thiazolidinones: Antimicrobial evaluation of indazole-4-thiazolidinone derivatives. Tetrahedron Lett. 2017, 58, 4632-4637. [CrossRef]

70. Dhar, B.V.; Bhanmik, A.; Reddy, P.Y. Synthesis, characterization and evaluation for antidepressant activities of some novel 4-thiazolidinone derivatives. Sch. Acad. J. Pharm. 2013, 2, 289-292.

71. Thérien, M.; Brideau, C.; Chan, C.C.; Cromlish, W.A.; Gauthier, J.Y.; Gordon, R.; Greig, G.; Kargman, S.; Lau, C.K.; Leblanc, Y.; et al. Synthesis and biological evaluation of 5,6-diarylimidazo[2.1-b]thiazole as selective COX-2 inhibitors. Bioorg. Med. Chem. Lett. 1997, 7, 47-52. [CrossRef]

72. Woods, K.W.; McCroskey, R.W.; Michaelides, M.R.; Wada, C.K.; Hulkower, K.I.; Bell, R.L. Thiazole analogues of the NSAID indomethacin as selective COX-2 inhibitors. Bioorg. Med. Chem. Lett. 2001, 11, 1325-1328. [CrossRef]

73. Suh, J.; Yum, E.K.; Cheon, H.G.; Cho, Y.S. Synthesis and Biological Evaluation of N-aryl-4-aryl-1,3Thiazole-2-Amine Derivatives as Direct 5-Lipoxygenase Inhibitors. Chem. Biol. Drug Des. 2012, 80, 89-98. [CrossRef] [PubMed]

74. Carradori, S.; Secci, D.; Bolasco, A.; De, M.; Yáñez, M. Synthesis and selective inhibitory activity against human COX-1 of novel 1-(4-substituted-thiazol-2-yl)-3,5-di(hetero)aryl-pyrazoline derivatives. Arch. Pharm. 2012, 345, 973-979. [CrossRef] [PubMed]

75. Assadieskandar, A.; Amini, M.; Salehi, M.; Sadeghian, H.; Alimardani, M.; Sakhteman, A.; Nadri, H.; Shafiee, A. Synthesis and SAR study of 4,5-diaryl- $1 H$-imidazole-2(3H)-thione derivatives, as potent 15-lipoxygenase inhibitors. Bioorg. Med. Chem. 2012, 20, 7160-7166. [CrossRef] [PubMed]

76. Tehrani, M.B.; Emami, S.; Asadi, M.; Saeedi, M.; Mirzahekmati, M.; Ebrahimi, S.M.; Mahdavi, M.; Nadri, H.; Moradi, A.; Moghadam, F.H.; et al. Imidazo[2,1-b]thiazole derivatives as new inhibitors of 15-lipoxygenase. Eur. J. Med. Chem. 2014, 87, 759-764. [CrossRef] [PubMed]

77. El-Achkar, G.A.; Jouni, M.; Mrad, M.F.; Hirz, T.; El, H.; Khalaf, A.; Hammoud, S.; Fayyad-Kazan, H.; Eid, A.A.; Badran, B.; et al. Thiazole derivatives as inhibitors of cyclooxygenases in vitro and in vivo. Eur. J. Pharmacol. 2015, 750, 66-73. [CrossRef] [PubMed]

78. Abdelazeem, A.H.; El-Saadi, M.T.; Safi, E.-D.; Omar, H.A.; El-Moghazy, S.M. Design, synthesis and analgesic/anti-inflammatory evaluation of novel diarylthiazole and diarylimidazole derivatives towards selective COX-1 inhibitors with better gastric profile. Bioorg. Med. Chem. 2017, 25, 665-676. [CrossRef] [PubMed]

79. Abdelazeem, A.H.; El-Saadi, M.T.; Said, E.G.; Youssif, B.G.M.; Omar, H.A.; El-Moghazy, S.M. Novel diphenylthiazole derivatives with multi-target mechanism: Synthesis, docking study, anticancer and anti-inflammatory activities. Bioorg. Chem. 2017, 75, 127-138. [CrossRef] [PubMed]

80. Ottaná, R.; Mazzon, E.; Dugo, L.; Monforte, F.; Maccari, R.; Sautebin, L.; De, L.; Vigorita, M.G.; Alcaro, S.; Ortuso, F.; et al. Modeling and biological evaluation of 3,3'-(1,2-ethanediyl)bis[2-(4-methoxyphenyl)thiazolidin-4-one], a new synthetic cyclooxygenase-2 inhibitor. Eur. J. Pharmacol. 2002, 448, 71-80. [CrossRef]

81. Vigorita, M.G.; Previtera, T.; Ottana, R.; Grillone, I.; Monforte, F.; Monforte, M.T.; Trovato, A.; Rossitto, A. 3,3'-Bi(1,3-thiazolidin-4-one) system. VIII. 3,3'-(1,2-Ethanediyl) derivatives and corresponding 1,1'-disulfones: Synthesis, stereochemistry and antiinflammatory activity. Farmaco 1997, 52, 43-48. [PubMed]

82. Vigorita, M.G.; Ottanà, R.; Monforte, F.; Maccari, R.; Trovato, A.; Monforte, M.T.; Taviano, M.F. Synthesis and antiinflammatory, analgesic activity of 3,3'-(1,2-ethanediyl)-bis[2-aryl-4-thiazolidinone] chiral compounds. Part 10. Bioorg. Med. Chem. Lett. 2001, 11, 2791-2794. [CrossRef]

83. Vigorita, M.G.; Ottanà, R.; Monforte, F.; Maccari, R.; Monforte, M.T.; Trovato, A.; Taviano, M.F.; Miceli, N.; De, L.; Alcaro, S.; et al. Chiral 3,3'-(1,2-Ethanediyl)-bis[2-(3,4-dimethoxyphenyl)-4-thiazolidinones] with anti-inflammatory activity. Part 11: Evaluation of COX-2 selectivity and modelling. Bioorg. Med. Chem. 2003, 11, 999-1006. [CrossRef]

84. Ottanà, R.; MacCari, R.; Barreca, M.L.; Bruno, G.; Rotondo, A.; Rossi, A.; Chiricosta, G.; Di, P.; Sautebin, L.; Cuzzocrea, S.; et al. 5-Arylidene-2-imino-4-thiazolidinones: Design and synthesis of novel anti-inflammatory agents. Bioorg. Med. Chem. 2005, 13, 4243-4252. [CrossRef] [PubMed] 
85. Di Rosa, M.; Willoughby, D.A. Screens for anti-inflammatory drugs. J. Pharm. Pharmacol. 1971, 23, $297-298$. [CrossRef] [PubMed]

86. Cuzzocrea, S.; Zingarelli, B.; Hake, P.; Salzman, A.L.; Szabo, C. Antiinflammatory effects of mercaptoethylguanidine, a combined inhibitor of nitric oxide synthase and peroxynitrite scavenger, in carrageenan-induced models of inflammation. Free Radic. Biol. Med. 1998, 24, 450-459. [CrossRef]

87. Zingarelli, B.; Southan, G.J.; Gilad, E.; O'Connor, M.; Salzman, A.L.; Szabó, C. The inhibitory effects of mercaptoalkylguanidines on cyclo-oxygenase activity. Br. J. Pharmacol. 1997, 120, 357-366. [CrossRef] [PubMed]

88. Taranalli, A.; Bhat, A.; Srinivas, S.; Saravanan, E. Antiinflammatory, analgesic and antipyretic activity of certain thiazolidinones. Indian J. Pharm. Sci. 2008, 70, 159-164. [CrossRef] [PubMed]

89. Geronikaki, A.A.; Lagunin, A.A.; Hadjipavlou-Litina, D.I.; Eleftheriou, P.T.; Filimonov, D.A.; Poroikov, V.V.; Alam, I.; Saxena, A.K. Computer-aided discovery of anti-inflammatory thiazolidinones with dual cyclooxygenase/lipoxygenase inhibition. J. Med. Chem. 2008, 51, 1601-1609. [CrossRef] [PubMed]

90. Hofmann, B.; Barzen, S.; Rödl, C.B.; Kiehl, A.; Borig, J.; Živkovi-, A.; Stark, H.; Schneider, G.; Steinhilber, D. A class of 5-benzylidene-2-phenylthiazolinones with high potency as direct 5-lipoxygenase inhibitors. J. Med. Chem. 2011, 54, 1943-1947. [CrossRef] [PubMed]

91. Hofmann, B.; Rödl, C.B.; Kahnt, A.S.; Maier, T.J.; Michel, A.A.; Hoffmann, M.; Rau, O.; Awwad, K.; Pellowska, M.; Wurglics, M.; et al. Molecular pharmacological profile of a novel thiazolinone-based direct and selective 5-lipoxygenase inhibitor. Br. J. Pharmacol. 2012, 165, 2304-2313. [CrossRef] [PubMed]

92. Hofmann, B.; Franke, L.; Proschak, E.; Tanrikulu, Y.; Schneider, P.; Steinhilber, D.; Schneider, G. Scaffold-hopping cascade yields potent inhibitors of 5-lipoxygenase. Chem. Med. Chem. 2008, 3, 1535-1538. [CrossRef] [PubMed]

93. Eleftheriou, P.; Geronikaki, A.; Hadjipavlou-Litina, D.; Vicini, P.; Filz, O.; Filimonov, D.; Poroikov, V.; Chaudhaery, S.S.; Roy, K.K.; Saxena, A.K. Fragment-based design, docking, synthesis, biological evaluation and structure-activity relationships of 2-benzo/benzisothiazolimino-5-aryliden-4-thiazolidinones as cycloxygenase/lipoxygenase inhibitors. Eur. J. Med. Chem. 2012, 47, 111-124. [CrossRef] [PubMed]

94. Unsal-Tan, O.; Ozadali, K.; Piskin, K.; Balkan, A. Molecular modeling, synthesis and screening of some new 4-thiazolidinone derivatives with promising selective COX-2 inhibitory activity. Eur. J. Med. Chem. 2012, 57, 59-64. [CrossRef] [PubMed]

95. Apostolidis, I.; Liaras, K.; Geronikaki, A.; Hadjipavlou-Litina, D.; Gavalas, A.; Soković, M.; Glamočlija, J.; Ćirić, A. Synthesis and biological evaluation of some 5-arylidene-2-(1,3-thiazol-2-ylimino)1,3-thiazolidin-4-ones as dual anti-inflammatory/antimicrobial agents. Bioorg. Med. Chem. 2013, 21, 532-539. [CrossRef] [PubMed]

96. Abdelazeem, A.H.; Salama, S.A.; Maghrabi, I.A. Design, Synthesis, and Anti-Inflammatory Evaluation of Novel Diphenylthiazole-Thiazolidinone Hybrids. Arch. Pharm. 2015, 348, 518-530. [CrossRef] [PubMed]

97. Abdellatif, K.R.A.; Abdelgawad, M.A.; Elshemy, H.A.H.; Alsayed, S.S.R. Design, synthesis and biological screening of new 4-thiazolidinone derivatives with promising COX-2 selectivity, anti-inflammatory activity and gastric safety profile. Bioorg. Chem. 2016, 64, 1-12. [CrossRef] [PubMed]

98. Ashour, H.M.A.; El-Ashmawy, I.M.; Bayad, A.E. Synthesis and pharmacological evaluation of new pyrazolyl benzenesulfonamides linked to polysubstitutedpyrazoles and thiazolidinones as anti-inflammatory and analgesic agents. Monatshefte für Chemie 2016, 147, 605-618. [CrossRef]

99. Ali, Y.; Alam, M.S.; Hamid, H.; Husain, A.; Dhulap, A.; Bano, S.; Kharbanda, C. Novel 2,4-dichlorophenoxy acetic acid substituted thiazolidin-4-ones as anti-inflammatory agents: Design, synthesis and biological screening. Bioorg. Med. Chem. Lett. 2017, 27, 1017-1025. [CrossRef] [PubMed]

100. Kouatly, O.; Eleftheriou, P.; Petrou, A.; Hadjipavlou-Litina, D.; Geronikaki, A. Docking assisted design of novel 4-adamantanyl-2-thiazolylimino-5-arylidene-4-thiazolidinones as potent NSAIDs. SAR QSAR Environ. Res. 2018, 29, 83-101. [CrossRef] [PubMed]

Sample Availability: Samples of the compounds are not available from the authors. 